\title{
Analisa Konsentrasi Khlorofil-A di Selat Madura Berbasis Nilai Algoritma dari Reflektan Citra Satelit Suomi-VIIRS
}

\author{
Siti Zainab ${ }^{1}$, Dian P. Solin ${ }^{1}$, Hendrata Wibisana ${ }^{1, *}$ \\ Departemen Teknik Sipil, Departemen Teknik Sipil, UPN “Veteran” Jawa Timur, Surabaya ${ }^{1}$ \\ Koresponden*, Email: hendrata2008@gmail.com
}

\section{Info Artike \\ Diajukan 28 Juli 2018}

Diperbaiki 05 Oktober 2018

Disetujui 17 Oktober 2018

Keywords: Chlorophyll-a, remote sensing algorithm, Suomi-VIIRS, surface reflectance

\begin{abstract}
Mapping of chlorophyll-a concentration has been done with many researchers to observe the condition of the water in the coastal area., the reason of this because of chlorophyll-a is one of the parameters which used by the researcher to predicted and measured the health of the water body. By knowing the value of chlorophyll-a concentration in those areas so it could be made an action of the process management at the coastal itself. In this research, the coastal which act as the case study are Madura strait, where the concentration of chlorophyll-a have been measured was taken in the area of Sampang district and Pamekasan district. This research used remote sensing technique by utilizing surface reflectance value from SuomiVIIRS satellite images which have 750 meter resolution. The value of chlorophyll-a concentration has been extracted from satellite images with the Seadass 7.2 programs and then following with the algorithm building which uses the wavelength of satellite images at the 410, 443, 551 and 671 nanometers (nm). From this result of the algorithm that has been created with statistical analysis, the result show that the band of $551 \mathrm{~nm}$ is more suitable than the others bands to figure the chlorophyll-a concentration, because the $551 \mathrm{~nm}$ is represented a green light from electromagnetic wavelength, and the processed results of statistics show the model that is most suitable for that is the form of linear and power models on channel $551 \mathrm{~nm}$, together with the value $R^{2}=0,83$ for linear model and $R^{2}=0,85$ for power.
\end{abstract}

\begin{abstract}
Abstrak
Pemetaan konsentrasi khlorofil-a sudah banyak dilakukan oleh para peneliti untuk memantau kondisi suatu perairan di laut lepas. Hal ini dikarenakan klorofil-a merupakan salah satu parameter yang digunakan untuk mengukur kesehatan suatu perairan. Dengan mengetahui nilai konsentrasi klorofil-a suatu daerah maka dapat dilakukan suatu aksi terhadap proses management daerah perairan tersebut. Pada penelitian ini daerah pesisir pantai yang diambil adalah daerah selat Madura, dimana konsentrasi klorofil-a yang diukur berada di Kabupaten Sampang dan Kabupaten Pamekasan. Penelitian ini menggunakan teknik penginderaan jauh dengan memanfaatkan nilai reflektan permukaan dari citra satelit Suomi-VIIRS yang memiliki resolusi 750 meter. Nilai konsentrasi klorofil-a diperoleh dari ekstraksi citra satelit dengan program SeaDASS 7.2 dan dilakukan penyusunan algoritma dengan pemanfaatan kanal citra satelit pada panjang gelombang 410, 443, 551 dan 671 nanometer. Dari hasil perhitungan algoritma yang ada diperoleh bahwa kanal pada panjang gelombang $551 \mathrm{~nm}$ lebih cocok untuk menggambarkan konsentrasi klorofil-a dibandingkan dengan kanal lainnya, hal ini mengingat bahwa panjang gelombang $551 \mathrm{~nm}$ mewakili panjang gelombang sinar hijau yang dihasilkan oleh gelombang elektromagnetik dari sinar matahari sebagai sumber energi yang ditangkap oleh sensor VIIRS ,dan hasil olahan statistik memperlihatkan model yang paling cocok untuk itu adalah bentuk model linier dan pangkat pada kanal $551 \mathrm{~nm}$, masing-masing dengan nilai $R^{2}=0,83$ untuk model linier dan $R^{2}=0,85$ untuk model pangkat.
\end{abstract}

Kata kunci: Khlorofil-a, algoritma penginderaan jauh, Suomi-VIIRS, reflektan permukaan pengembangan lebih jauh terdapat daerah perairan tersebut [1][2]. Keberadaan klorofil-a berhubungan erat dengan kandungan phytoplakton yang tersebar pada daerah tersebut, dimana phytoplakton merupakan salah satu bagian dari rantai makanan yang sangat dibutuhkan oleh ikan-ikan kecil untuk pertumbuhannya. Dapat dikatakan bahwa dengan banyaknya konsentrasi klorofil-a yang terdeteksi pada suatu sehingga dengan adanya indikasi seperti ini dapat dilakukan 
badan air maka dapat dipastikan bahwa dalam perairan tersebut tersedia phytoplakton dalam jumlah yang cukup untuk keberlangsungan adanya rantai makanan bagi ikanikan yang ada. Indonesia merupakan salah satu negara bahari yang memiliki luas perairan yang besar, jauh lebih besar dari luas daratannya, sehingga kebanyakan masyarakat yang hidup di daerah pesisir merupakan masyarakat yang menggantungkan hidupnya dengan melakukan usaha penangkapan ikan dan budidaya hewan laut.

Salah satu daerah yang cukup dinamis perkembangan dan pertumbuhan perikanan tangkap yaitu pada pesisir pantai di daerah selat Madura, dimana pesisir pantai daerah kabupaten Sampang dan Pamekasan merupakan daerah perikanan dimana masyarakatnya menggantungkan kepada mata pencaharian dari melaut dan penangkapan ikan. Kesejahteraan masyarakat daerah pesisir Sampang dan Pamekasan disini sangat tergantung dari tingkat kesuburan perairan yang ada di selat Madura, dimana salah satu program pemerintah yaitu ketahanan pangan daerah serta peningkatan kesejahteraan masyarakat pesisir ikut menentukan keberlangsungan pembangunan daerah tersebut.

Untuk dapat memantau daerah yang cukup besar seperti selat Madura dibutuhkan suatu teknologi yang mampu untuk memantau serta mendekeksi areal yang luas secara terus menerus dengan selang waktu yang dapat diprediksikan. Salah satu teknologi tersebut adalah penginderaan jauh, dimana teknologi ini mampu untuk melakukan pemantauan lewat perekaman data secara temporal sehingga setiap selang waktu tertentu dapat diamati perkembangan area yang dideteksi. Teknologi penginderaan jauh sudah banyak dilakukan untuk pemantauan daerah skala yang luas dengan berbagai macam satelit dan sensor yang ada [3][4]. Teknologi yang dikembangkan dengan berbagai sensor perekaman meliputi sensor Thematic mapper dari Landsat 5, ETM+ dari Landsat 7, OLI-TIRS dari Landsat 8 [5][6], AVHRR dari satelit NOAA, satelit MERIS [7] serta MODIS [8][9] dari satelit Terra dan Aqua [10]. Jenis pemantauan yang sering dilakukan pada perairan di pesisir pantai dan laut lepas adalah suhu permukaan laut (sea surface temperature), $\mathrm{pH}$ air laut, salinitas air laut dan keberadaan klorofil-a [11] [12] [13].

Beberapa parameter tersebut turut menentukan tingkat kesehatan dari suatu perairan, dan parameter-parameter tersebut saling berinteraksi baik secara langsung maupun tidak langsung dalam mengubah ekosistem yang ada pada lingkungan perairan dan pada akhirnya akan mempengaruhi biota yang ada pada badan air tersebut, apabila suhu permukaan laut berubah maka sedikit banyak akan mempengaruhi ikan-ikan yang tumbuh di daerah tersebut, demikian juga dengan $\mathrm{pH}$ air apabila mengalami kanikan akan mempengaruhi nilai salinitas air laut, dan pada akhirnya akan mengganggu kehidupan phytoplakton yang ada di daerah tersebut, phytoplaktyon berkurang maka konsentrasi klororfil juga mengecil demikian pula terjadi sebaliknya.

Tujuan dari penelitian ini untuk mendapatkan gambaran konsentrasi klorofil-a yang ada pada daerah selat Madura tepatnya pada pesisir pantai kabupaten Sampang dan Pamekasan yang berdekatan, dimana dari peta tematis yang dihasilkan berupa kandungan konsentrasi klorofil-a pada daerah tersebut akan membantu dalam proses manajemen daerah pesisir pada waktu yang akan datang. Penggunakan citra satelit dimaksudkan sebagai salah satu teknologi yang dikembangkan dalam penelitian ini agar daerah yang luas dapat diidentifikasi dengan baik dan memiliki keakuratan yang tinggi dengan bantuan pengolahan data sattistik untuk mendapatkan nilai korelasi dari parameter konsentrasi klorofil-a terhadap nilai reflektan dari kanal citra satelit VIIRS dengan beberapa panjang gelombang yang bersesuaian dengan pendeteksian konsentrasi klorofil-a.

\section{Metode}

Penelitian ini mengambil daerah pesisir pantai di selat Madura tepatnya pada kabupaten Sampang dan kabupaten Pamekasan. Untuk membatasi koordinat area penelitian dilakukan pengambilan data citra satelit Suomi -VIIIRS pada laman http://oceandata.sci.gsfc.nasa.gov/ dan pemilihan tanggal akuisisi yaitu pada tanggal 4 Oktober 2017 dengan nama file citra satelit V201726106000_L2_SNPP_OC.nc, level prosesing adalah L2, tampilan lokasi di pesisir pantai Pulau Madura diperlihatkan pada Gambar 1.

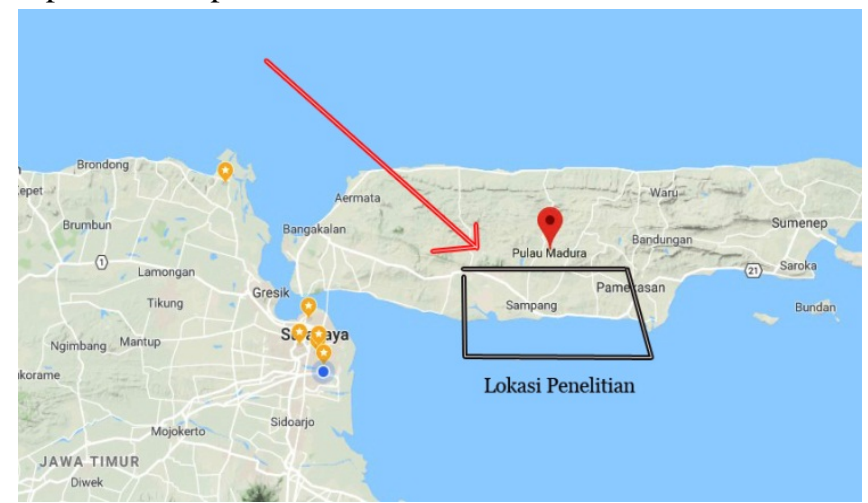

Gambar 1. Peta lokasi penelitian di pesisir pantai Pulau Madura 
Untuk citra satelit dengan warna komposit diperlihatkan pada Gambar 2. Dimana pada Gambar 2 tersebut memperlihatkan cakupan area yang sangat luas, hal ini dikarenakan untuk citra suomi -VIIRS ini memiliki resolusi spasial 750 meter hingga $1 \mathrm{~km}$.

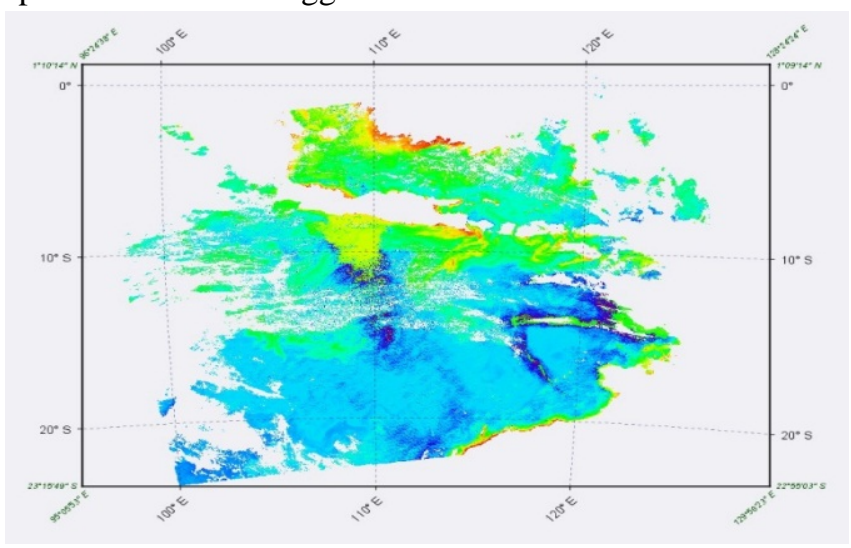

Gambar 2. Tampilan citra satelit Suomi -VIIRS yang diakses pada tanggal 4 Oktober 2017 pada daerah pulau Jawa dan sekitarnya dengan bentuk warna tampilan citra berupa warna komposit.

Proses selanjutnya adalah reprojeksi citra satelit dan dilanjutkan dengan pemotongan citra untuk daerah penelitian di Selat Madura, hasil pemotongan diperlihatkan pada Gambar 3, yang sudah memiliki proyeksi WGS 84. Pengambilan nilai surface reflektan dari citra dilakukan dengan menggunakan SeaDASS 7.2. dan diperoleh nilai untuk masing-masing panjang gelombang yang ada pada citra satelit serta konsentrasi klorofil-a, panjang gelombang yang digunakan adalah $410 \mathrm{~nm}, 443 \mathrm{~nm}, 551 \mathrm{~nm}$ dan 671 $\mathrm{nm}$. Adapun flowchart penelitian ini diperlihatkan pada Gambar 4.

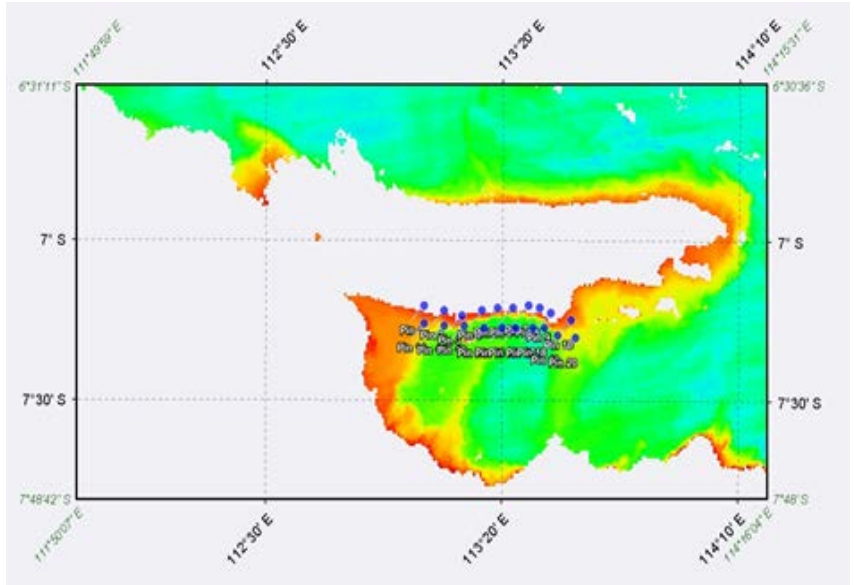

Gambar 3. Hasil pemotongan citra satelit dan koordinat pengambilan data reflektan permukaan dan konsentrasi klorofil-a dalam mg/l

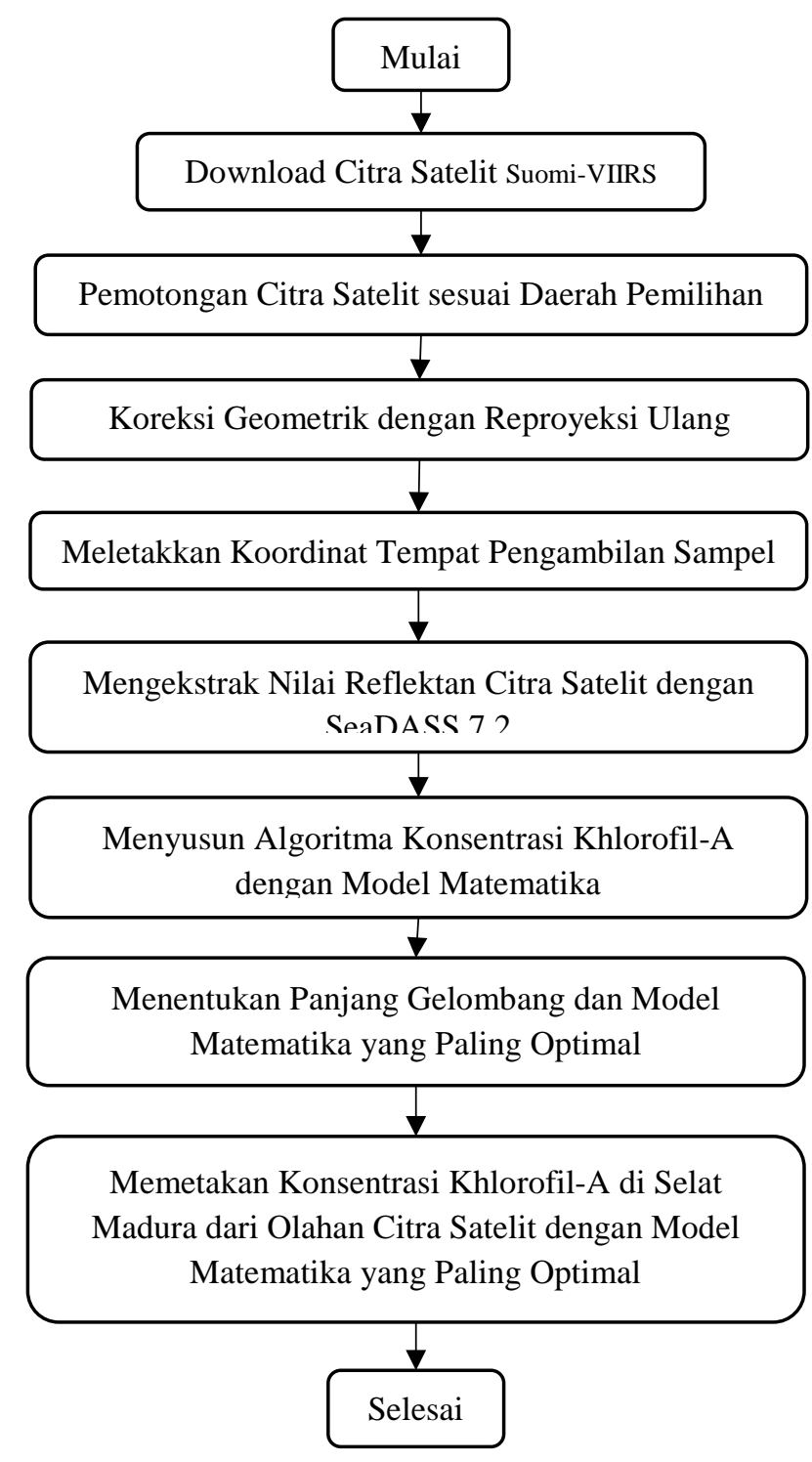

Gambar 4. Diagram alir pemakaian reflektan citra satelit mulai perolehan citra hingga pemetaan klorofil-a

\section{Algoritma Penginderaan Jauh}

Algoritma yang disusun dalam penelitian ini meliputi 4 model matematis yang diurutkan sebagai berikut:

a. Model Linier dengan bentuk persamaan matematis

$$
y=a+b . x
$$

b. Model Eksponen dengan bentuk persamaan matematis

$$
y=a \cdot e^{b . x}
$$

c. Model Logaritmik dengan bentuk persamaan matematis

$$
y=a+b \cdot \ln (x)
$$

d. Model Pangkat dengan bentuk persamaan matematis

$$
y=a \cdot x^{b}
$$

Dimana, y adalah variabel tak bebas, $\mathrm{x}$ adalah variabel bebas, a dan b adalah koefisien. 


\section{Hasil dan Pembahasan}

Dengan menggunakan program SeaDASS 7.2 dilakukan proses ekstraksi nilai konsentrasi klorofil-a citra satelit Suomi-VIIRS pada titik koordinat yang dipilih searah jalur pesisir pantai Kabupaten Sampang dan Kabupaten Pamekasan. Hal ini dapat dilihat pada Gambar 3, sedangkan hasil ekstraksi yang dilakukan dengan program SeaDASS 7.2 dapat diperlihatkan pada Tabel 1 .

Tabel 1. Ekstraksi nilai konsentrasi klorofil-a pada koordinat terpilih

\begin{tabular}{cccc}
\hline Titik & Longitude & Latitude & $\begin{array}{c}{[\text { Khlor }]} \\
\text { mg/liter }\end{array}$ \\
\hline 1 & 112,9201 & $-7,2330$ & 33,5649 \\
2 & 112,9829 & $-7,2562$ & 26,7583 \\
3 & 113,0691 & $-7,2714$ & 17,8268 \\
4 & 113,1476 & $-7,2946$ & 0,5548 \\
5 & 113,2886 & $-7,2704$ & 0,5118 \\
6 & 113,3983 & $-7,2776$ & 0,3576 \\
7 & 113,4926 & $-7,3162$ & 0,3130 \\
8 & 113,6177 & $-7,2686$ & 15,7449 \\
9 & 113,6877 & $-7,1900$ & 11,6779 \\
10 & 113,7894 & $-7,1737$ & 15,2901 \\
11 & 113,9380 & $-7,1337$ & 14,3709 \\
12 & 114,0399 & $-7,1565$ & 0,9400 \\
13 & 114,1019 & $-7,0622$ & 19,3295 \\
14 & 114,1644 & $-7,0383$ & 10,1036 \\
15 & 114,2029 & $-6,9443$ & 0,7951 \\
16 & 112,9208 & $-7,4051$ & 28,3666 \\
17 & 112,9524 & $-7,4676$ & 28,9566 \\
18 & 112,9841 & $-7,5301$ & 1,3697 \\
19 & 113,0392 & $-7,5690$ & 11,1132 \\
20 & 113,1021 & $-7,6000$ & 21,0195 \\
\hline
\end{tabular}

Setelah diperoleh nilai konsentrasi klorofil-a maka dilakukan ekstraksi nilai reflektan permukaan yang diperlihatkan pada Tabel 2., untuk masing-masing kanal pada panjang gelombang yang digunakan adalah $410 \mathrm{~nm}$, $443 \mathrm{~nm}, 551 \mathrm{~nm}$ dan $671 \mathrm{~nm}$.

Dari Tabel 2 tersebut dilakukan pemrosesan images citra satelit untuk mendapatkan algoritma yang sudah disusun sebelumnya dengan berbagai model matematik yang dapat menggambarkan kondisi dari konsentrasi klorofil-a di Selat Madura. Perhitungan pertama dilakukan pada panjang gelombang $410 \mathrm{~nm}$ dari citra satelit. Hasil dari perhitungan ini diberikan pada Tabel 3 untuk model algoritme linier, eksponen, logaritmik dan pangkat.

Tabel 3 memperlihatkan keragaman nilai korelasi $\mathrm{R}^{2}$, dimana dari beberapa model matematik yang ada untuk panjang gelombang 410 nilai $\mathrm{R}$ yang tertinggi dipenuhi oleh algoritma pangkat dengan $\mathrm{R}^{2}=0,7721$. Adapun gambaran untuk masing-masing model matematis diberikan pada Gambar 3 beserta dengan nilai $\mathrm{R}^{2}$ dan model matematisnya.

Tabel 2. Ekstraksi nilai reflektan permukaan citra satelit Suomi-VIIRS pada koordinat yang sudah dipilih

\begin{tabular}{ccccc}
\hline Rrs_410 & Rrs_443 & Rrs_551 & Rrs_671 & chlor_a (mg/l) \\
\hline 0,00969 & 0,01268 & 0,02415 & 0,00899 & 33,5649 \\
0,01074 & 0,01468 & 0,02473 & 0,00740 & 26,7583 \\
0,00534 & 0,00797 & 0,01318 & 0,00195 & 17,8268 \\
0,00172 & 0,00210 & 0,00250 & 0,00220 & 0,5548 \\
0,00160 & 0,00183 & 0,00214 & 0,00154 & 0,5118 \\
0,00187 & 0,00263 & 0,00187 & 0,00084 & 0,3576 \\
0,00818 & 0,01166 & 0,01659 & 0,00281 & 15,7449 \\
0,00713 & 0,01033 & 0,01382 & 0,00176 & 11,6779 \\
0,00768 & 0,01136 & 0,01687 & 0,00254 & 15,2901 \\
0,00852 & 0,01252 & 0,01721 & 0,00274 & 14,3709 \\
0,00714 & 0,00983 & 0,01145 & 0,00122 & 0,9400 \\
0,01023 & 0,01517 & 0,02261 & 0,00443 & 19,3295 \\
0,00698 & 0,00975 & 0,01174 & 0,00128 & 10,1036 \\
\hline
\end{tabular}

Tabel 3. Resume Algoritma penginderaan jauh untuk kanal Rrs $443 \mathrm{~nm}$

\begin{tabular}{cccc}
\hline No & Algoritme & Model matematis & $\mathrm{R}^{2}$ \\
\hline 1 & Linier & $\mathrm{y}=2667 \mathrm{x}-4,9626$ & 0,6515 \\
2 & Eksponen & $\mathrm{y}=0,2772 \mathrm{e}^{459,49 x}$ & 0,7452 \\
3 & Logaritmik & $\mathrm{y}=11,391 \ln (\mathrm{x})+71,87$ & 0,5749 \\
4 & Pangkat & $\mathrm{y}=363689 \mathrm{x}^{2,1265}$ & 0,7721 \\
\hline
\end{tabular}

Tabel 3. Resume Algoritma penginderaan jauh untuk kanal Rrs_443 nm

\begin{tabular}{cccc}
\hline No & Algoritme & Model matematis & $\mathrm{R}^{2}$ \\
\hline 1 & Linier & $\mathrm{y}=1791,1 \mathrm{x}-4,0307$ & 0,6103 \\
2 & Eksponen & $\mathrm{y}=0,2868 \mathrm{e}^{322 \mathrm{x}}$ & 0,7601 \\
3 & Logaritmik & $\mathrm{y}=10,293 \ln (\mathrm{x})+62,853$ & 0,5477 \\
4 & Pangkat & $\mathrm{y}=84007 \mathrm{x}^{1,9663}$ & 0,7704 \\
\hline
\end{tabular}

Perhitungan algoritma model matematis untuk konsentrasi klorofil-a diperlihatkan pada Tabel 4., dimana panjang gelombang yang ada adalah $443 \mathrm{~nm}$. Pada panjang gelombang ini nilai korelasi yang tertinggi ada pada algoritma model pangkat dengan nilai $\mathrm{R}^{2}=0,7704$. Untuk gambaran hasil analisa statistik pada grafik scatter diberikan pada Gambar 5. 


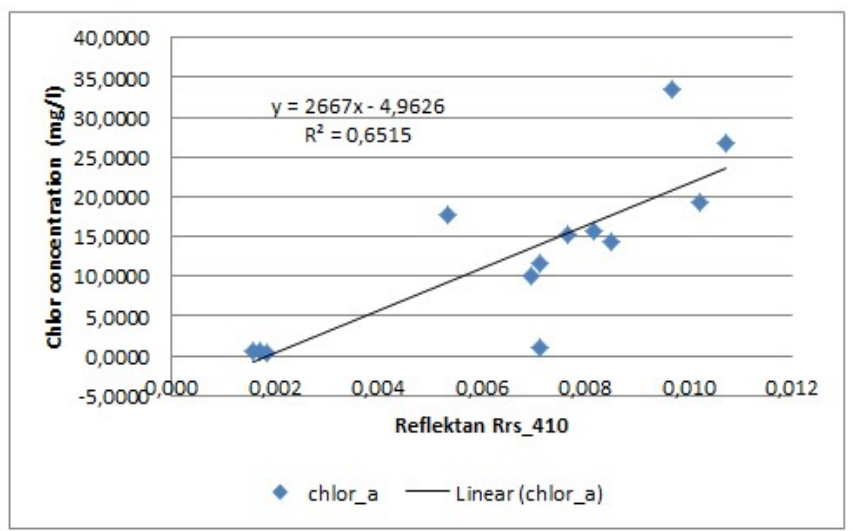

[A]

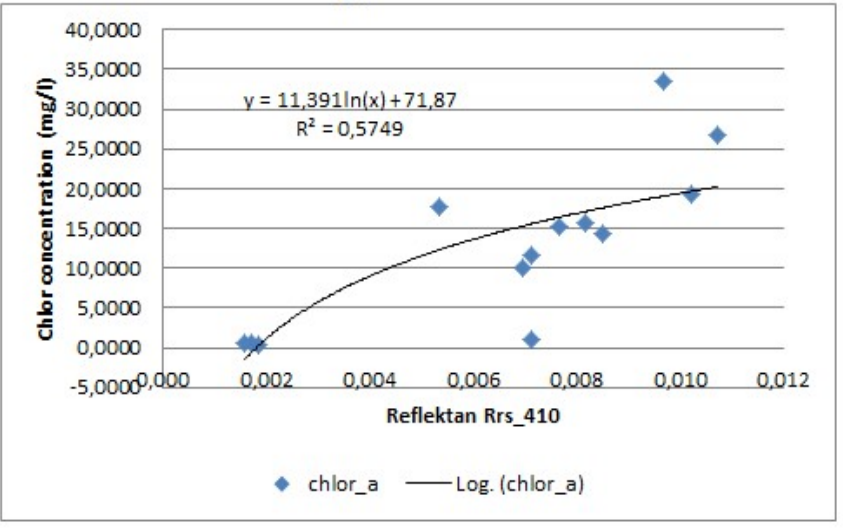

[C]

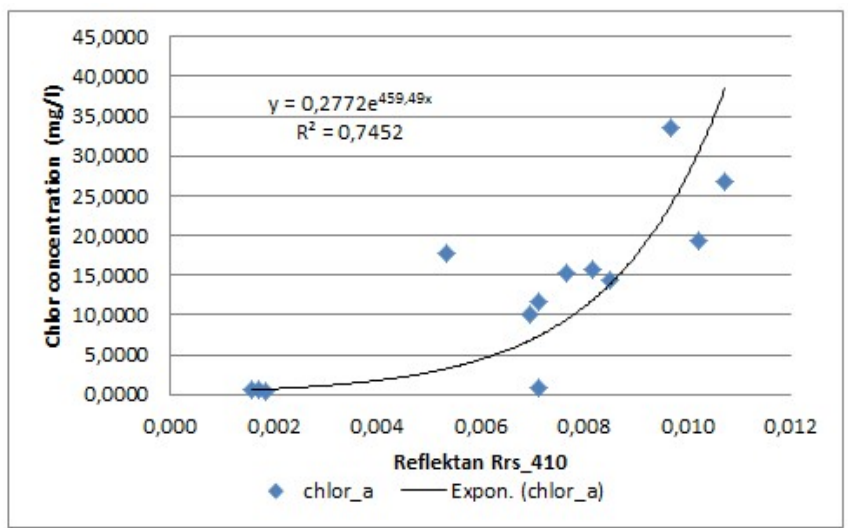

[B]

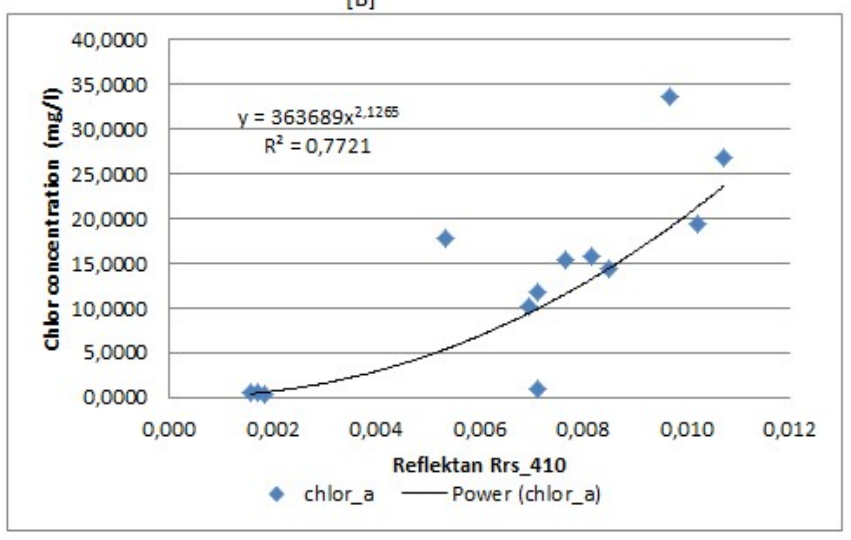

[D]

Gambar 5. Perbandingan algoritma penginderaan jauh dengan nilai reflektan untuk kanal Rrs_410. [A] linier, [B] eksponen, [C] logaritmik, [D] power

Tabel 5. Resume Algoritma penginderaan jauh untuk kanal Rrs_551 nm

\begin{tabular}{cccc}
\hline No & Algoritme & Model matematis & $\mathrm{R}^{2}$ \\
\hline 1 & Linier & $\mathrm{y}=1210,3 \mathrm{x}-3,8017$ & 0,8338 \\
2 & Eksponen & $\mathrm{y}=0,4169 \mathrm{e}^{193,39 \mathrm{x}}$ & 0,8204 \\
3 & Logaritmik & $\mathrm{y}=9,1926 \ln (\mathrm{x})+54,854$ & 0,6683 \\
4 & Pangkat & $\mathrm{y}=12695 \mathrm{x}^{1,6771}$ & 0,8572 \\
\hline
\end{tabular}

Tabel 5 memperlihatkan hasil perhitungan algoritma penginderaan jauh pada panjang gelombang $551 \mathrm{~nm}$. Disini terlihat bahwa nilai korelasi yang tertinggi diperoleh algoritma model pangkat dengan nilai $\mathrm{R}^{2}=0,8572$. Disini dapat dijelaskan bahwa sekitar 85,72\% data reflektan dapat memberikan gambaran konsentrasi nilai klorofil-a di lapangan. Gambaran grafik scatter untuk panjang gelombang 551 diberikan pada Gambar 5., sedangkan untuk peta tematis citra satelit sebaran reflektan dari panjang gelombang Rrs_551 diberikan pada Gambar 7.
Tabel 6. Resume Algoritma penginderaan jauh untuk kanal Rrs_671 nm

\begin{tabular}{cccc}
\hline No & Algoritme & Model matematis & $\mathrm{R}^{2}$ \\
\hline 1 & Linier & $\mathrm{y}=3650,8 \mathrm{x}+1,7034$ & 0,7476 \\
2 & Eksponen & $\mathrm{y}=1,7427 \mathrm{e}^{402,97 \mathrm{x}}$ & 0,3510 \\
3 & Logaritmik & $\mathrm{y}=13,344 \ln (\mathrm{x})+93,349$ & 0,7764 \\
4 & Pangkat & $\mathrm{y}=168013 \mathrm{x}^{1,6984}$ & 0,4847 \\
\hline
\end{tabular}

Tabel 6 memperlihatkan hasil perhitungan algoritma penginderaan jauh untuk panjang gelombang $671 \mathrm{~nm}$, dimana korelasi yang terbesar didapatkan pada model logaritmik dengan nilai $\mathrm{R} 2=0,7764$. Hal ini memiliki arti bahwa secara statistik hanya 77,64\% reflektan dari citra satelit yang dapat menggambarkan nilai konsentrasi dari klorofil-a di lapangan. Gambaran grafik scatter untuk panjang gelombang 671 ini diberikan pada Gambar 6 . 


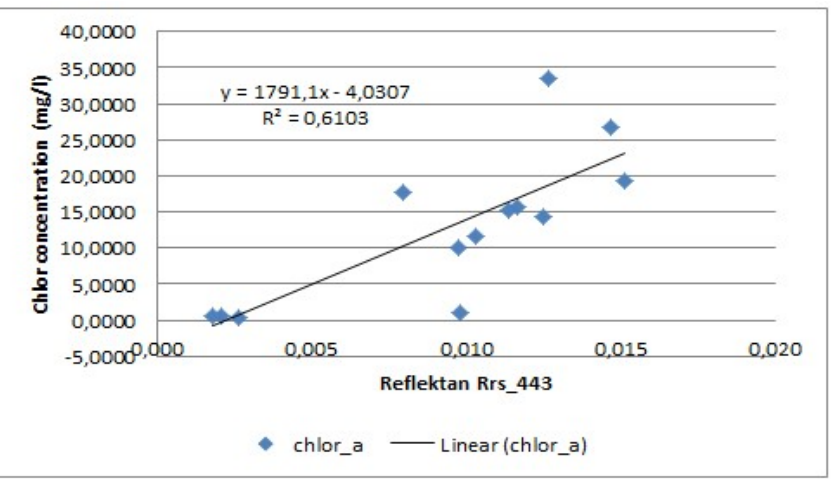

[A]

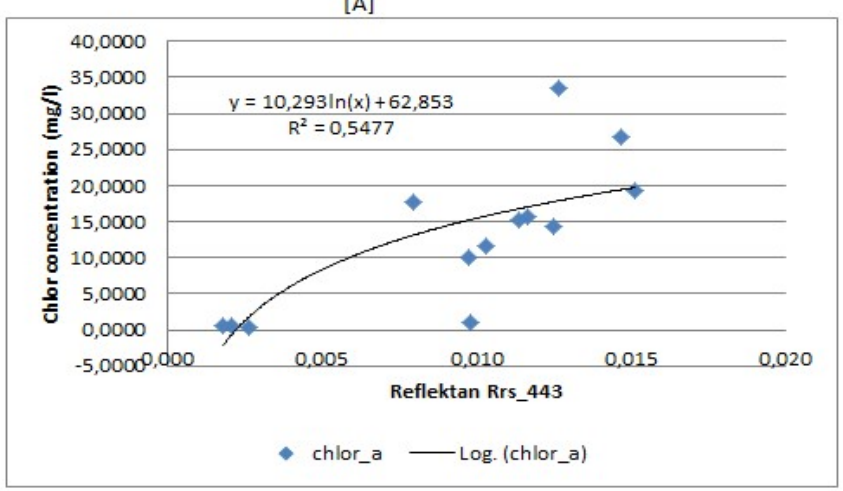

[c]

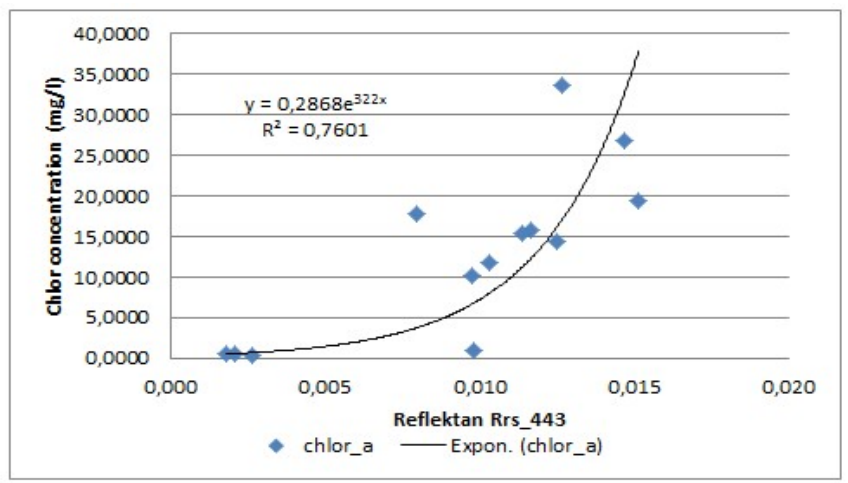

[B]

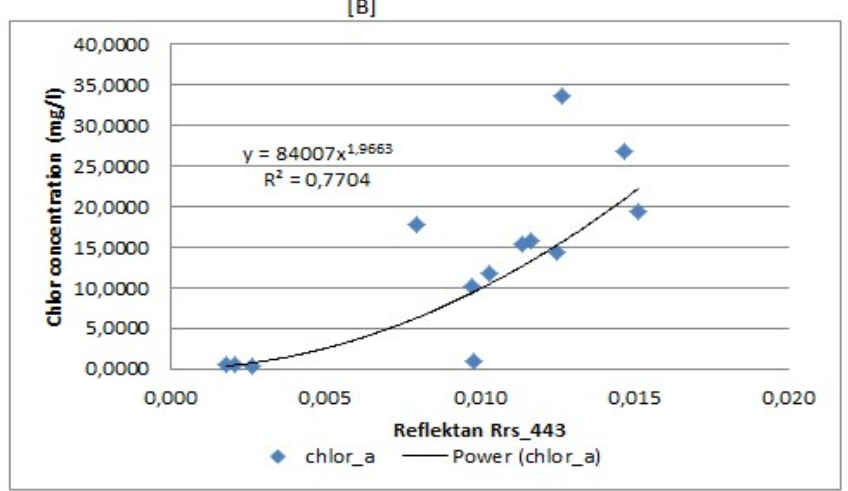

[D]

Gambar 6. Perbandingan algoritma penginderaan jauh dengan nilai reflektan untuk kanal Rrs_443. [A] linier, [B] eksponen, [C] logaritmik, [D] power

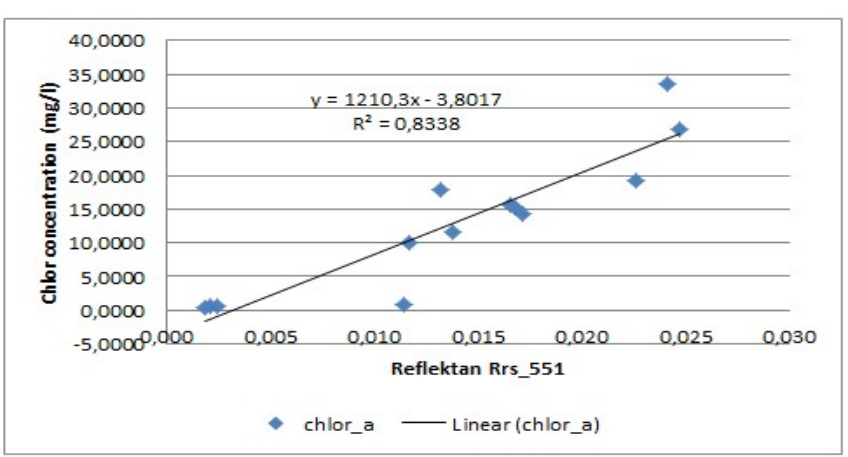

[A]

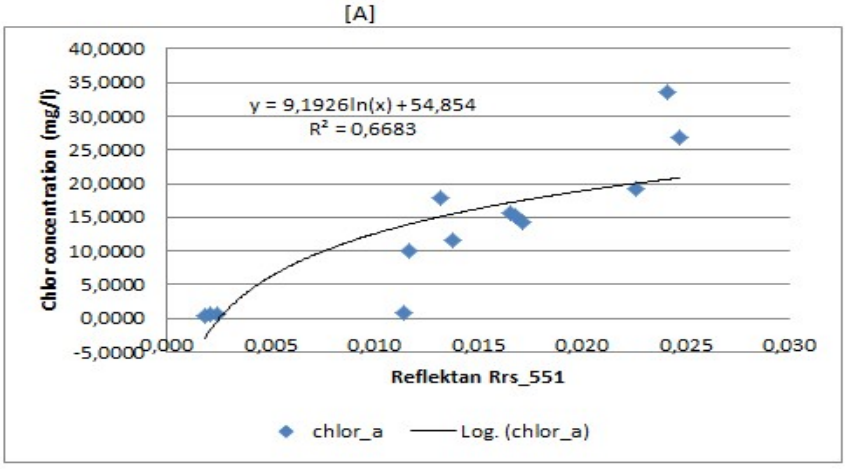

[C]

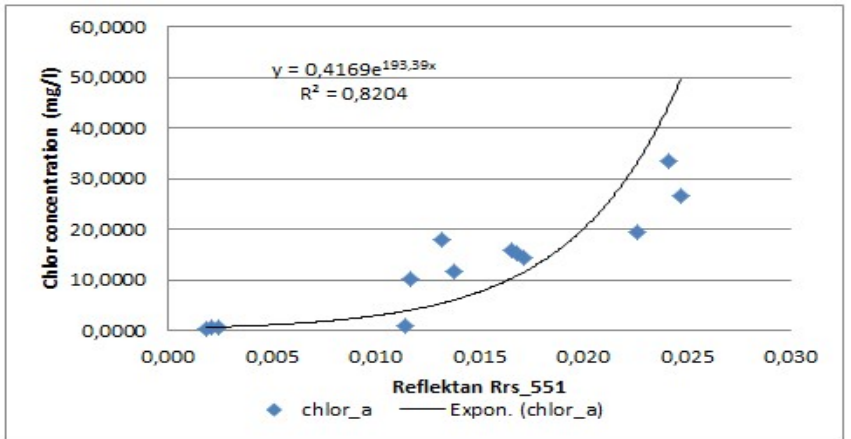

[B]

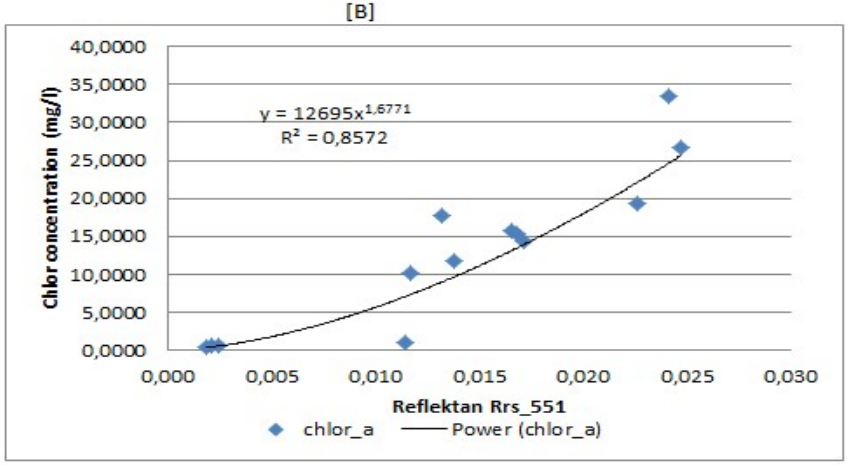

[D]

Gambar 7. Perbandingan algoritma penginderaan jauh dengan nilai reflektan untuk kanal Rrs_551. [A] linier, [B] eksponen, [C] logaritmik, [D] power 


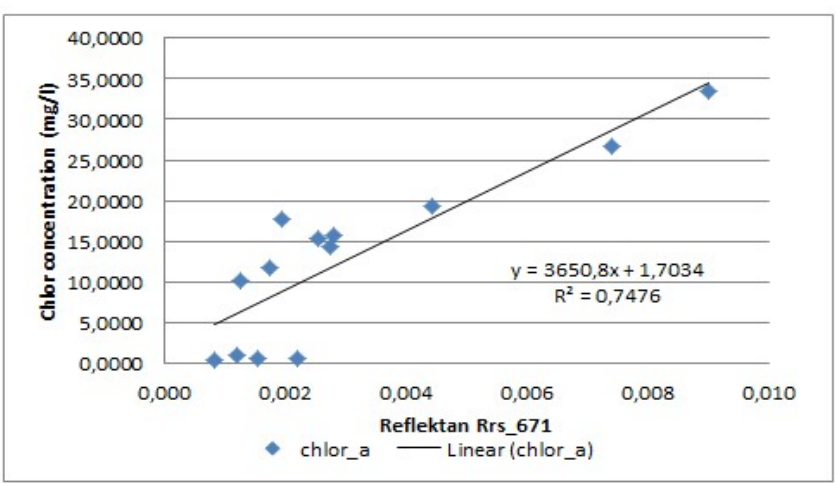

[A]

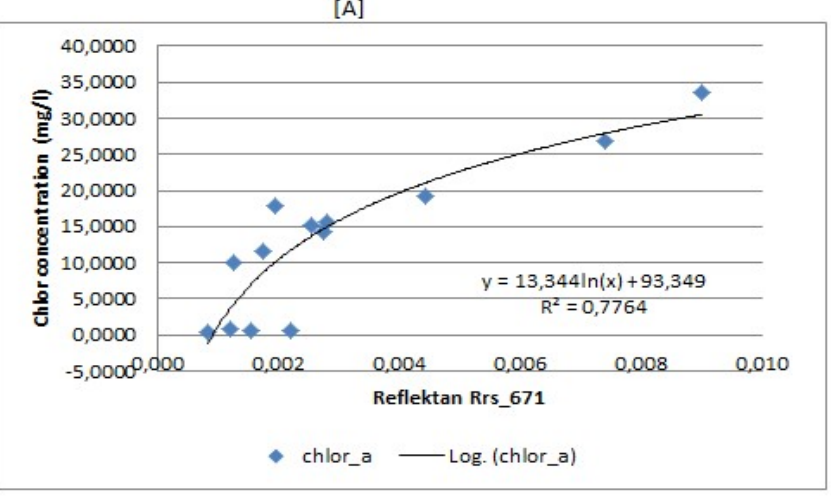

[C]

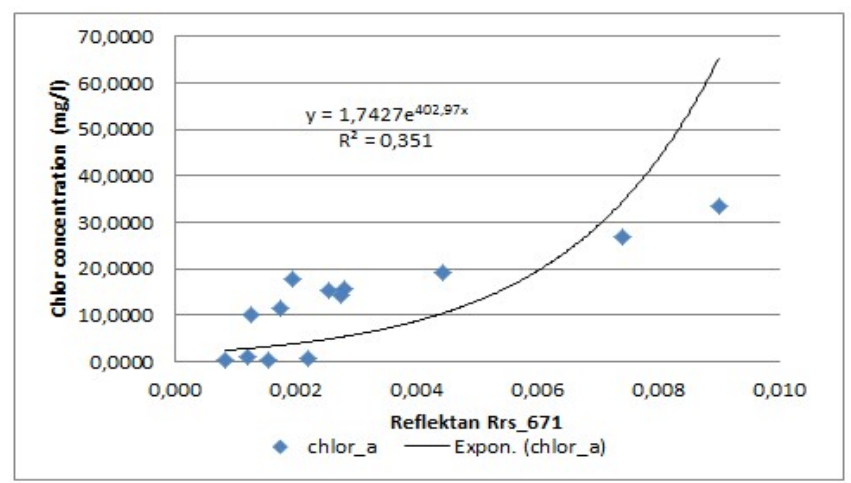

[B]

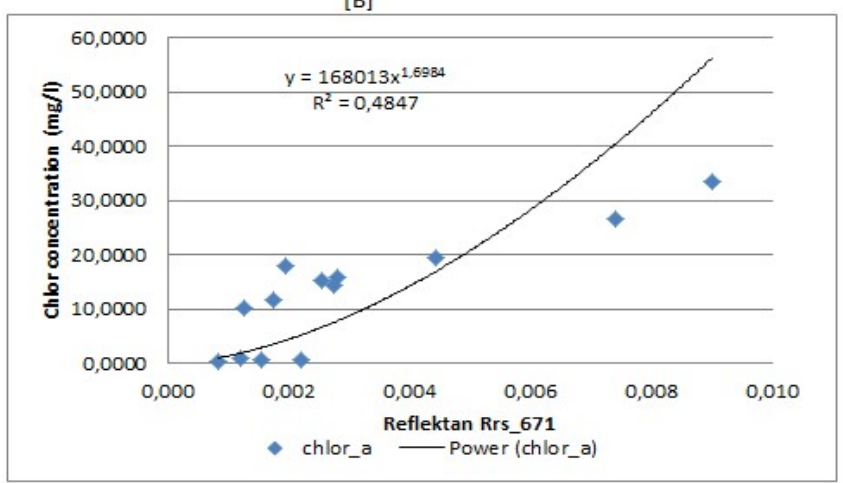

[D]

Gambar 8. Perbandingan algoritma penginderaan jauh dengan nilai reflektan untuk kanal Rrs_671. [A] linier, [B] eksponen, [C] logaritmik, [D] power

Gambar 9 memperlihatkan warna komposit dari citra satelit Suomi VIIRS untuk daerah selat Madura dan sekitarnya. Ekstrak reflektan pada panjang gelombang 551 nm diberikan pada Gambar tersebut dimana nilai reflektan berkisar antara 0 hingga nilai 1 , untuk lingkungan perairan nilai ini biasanya tersebar seperti yang diperlihatkan pada Tabel 2, sebelumnya baik untuk panjang gelombang 551 nm ataupun panjang gelombang lainnya.

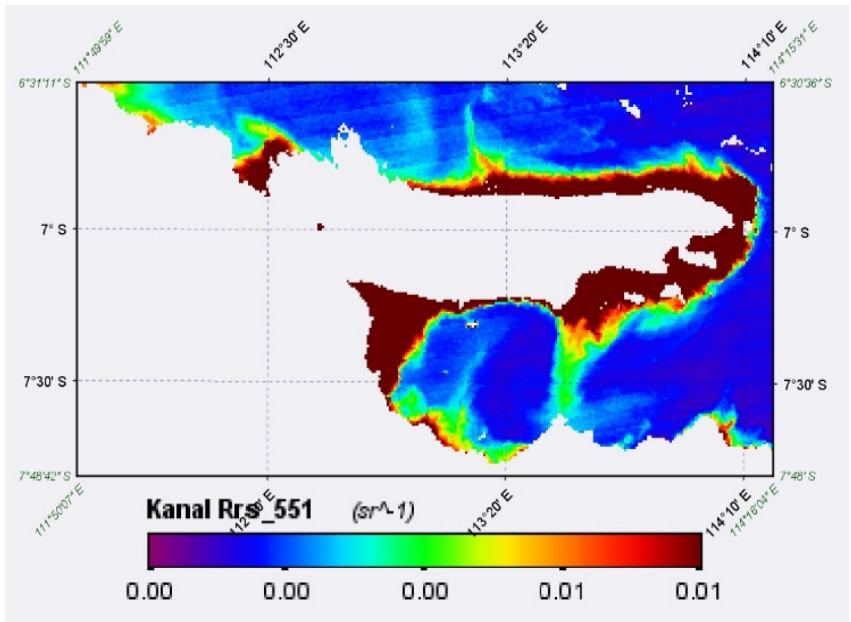

Gambar 9. Peta tematis reflektan permukaan dari citra satelit Suomi VIIRS pada panjang gelombang $551 \mathrm{~nm}$
Setelah melalui proses perhitungan dengan menggunakan Math band pada SeaDASS maka dapat diperoleh peta tematis untuk masing-masing algoritma yang dikehendaki. Dalam penelitian ini diperlihatkan algoritma model linier untuk panjang gelombang $551 \mathrm{~nm}$ yang menghasilkan kesesuaian yang paling tinggi dilihat dari korelasi nilai R2, dan untuk peta tematis ditampilkan pada Gambar 10.

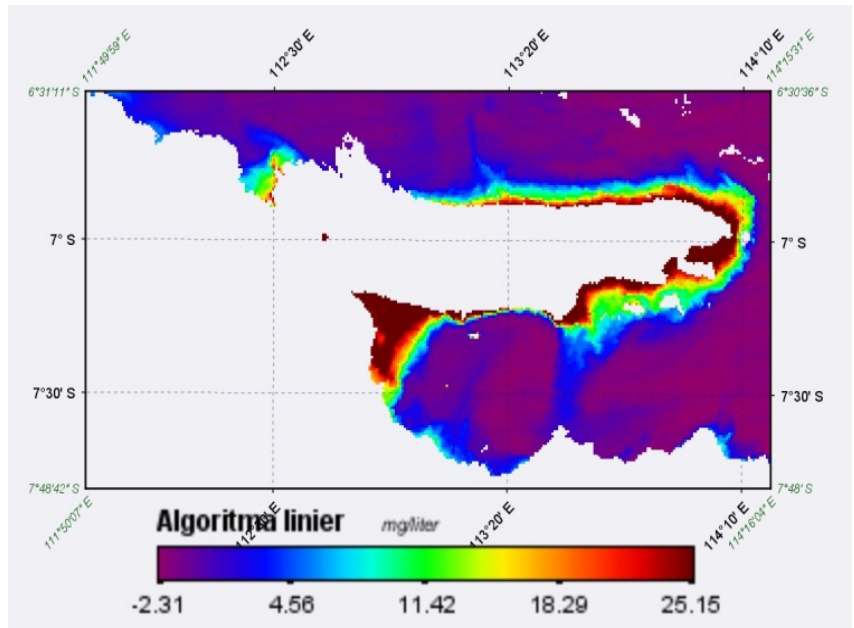

Gambar 10. Peta tematis konsentrasi klorofil-a dengan algoritma linier panjang gelombang $551 \mathrm{~nm}$. 
Untuk Gambar 11 merepresentasikan konsentrasi klorofil-a dengan menggunakan algoritma pangkat (power), sedangkan diagram scattter yang menunjukkan analisa statistik algoritma pangkat ini sudah diperlihatkan pada Gambar 5.

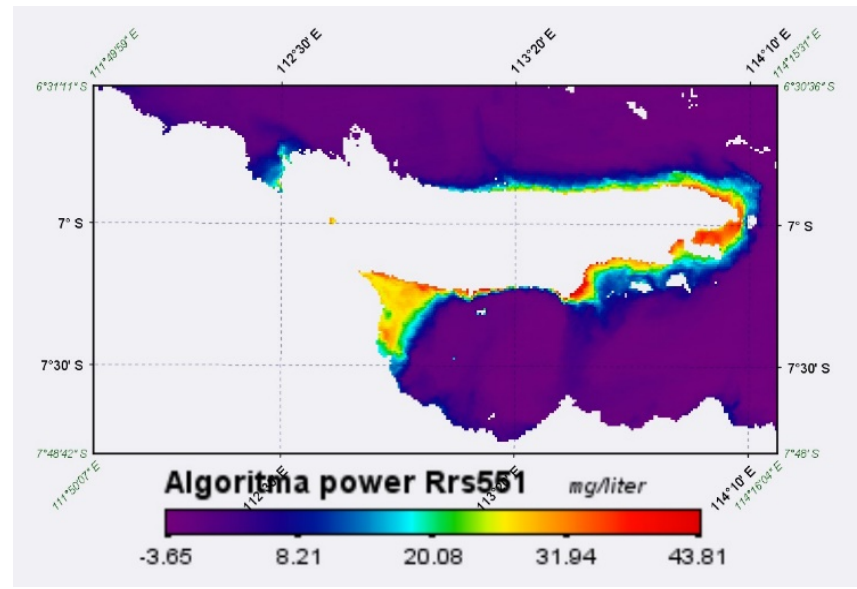

Gambar 11. Peta Tematis konsentrasi klorofil-a dengan algoritma pangkat/power panjang gelombang $551 \mathrm{~nm}$

\section{Simpulan}

Konsentrasi klorofil-a pada daerah Selat Madura memiliki keragaman yang tergantung kepada lokasi koordinat dari titik pengambilan data, dimana untuk daerah kabupaten Sampang konsentrasi klorofil-a relatif lebih sedikit dibandingkan dengan pesisir pantai kabupaten Pamekasan.

Algoritma yang disusun untuk memetakan konsentrasi klorofil-a dengan berdasarkan nilai reflektan citra satelit menghasilkan model linier dan model pangkat yang memiliki nilai korelasi $\mathrm{R}$ yang paling tinggi dengan nilai $\mathrm{R} 2=0,8338$ dan $\mathrm{R} 2=0,8575$ untuk masing-masing model.

Panjang gelombang yang paling optimum untuk menggambarkan konsentrasi klorofil-a adalah $551 \mathrm{~nm}$. Hal ini mengingat bahwa panjang gelombang $551 \mathrm{~nm}$ adalah representasi dari sinar hijau yang terdapat pada gelombang elektromagnetik sinar tampak pancaran dari sinar matahari yang mengenai zat hijau daun dari klorofil-a dan ditangkap oleh sensor pada citra satelit Suomi-VIIRS. Model matematis yang dihasilkan adalah $[C h l-a]=1210,3 * R^{*} s_{2} 551-3,8017$ untuk linier dan $\quad[$ Chl $-a]=12695 * \operatorname{Rrs}_{-} 551^{1,6771} \quad$ untuk pangkat.

\section{Daftar Pustaka}

[1] V. Nii and A. Narteh, "Mapping and Modeling Chlorophyll-a Concentrations in Utah Lake Using Landsat 7 ETM + Imagery,” 2011.
[2] S. Vazyulya, A. Khrapko, O. Kopelevich, V. Burenkov, T. Eremina, and A. Isaev, "Regional algorithms for the estimation of chlorophyll and suspended matter concentration in the Gulf of Finland from MODIS-Aqua satellite data *,” no. 11, 2014.

[3] C. Giardino et al., "Evaluation of multi-resolution satellite sensors for assessing water quality and bottom depth of Lake Garda," Sensors (Switzerland), vol. 14, no. 12, pp. 24116-24131, 2014.

[4] S. Sterckx, E. Knaeps, M. Bollen, K. Trouw, and R. Houthuys, "Retrieval of suspended sediment from advanced hyperspectral sensor data in the Scheldt estuary at different stages in the tidal cycle," Mar. Geod., vol. 30, no. 1-2, pp. 97-108, 2007.

[5] Z. Zheng, Y. Li, Y. Guo, Y. Xu, G. Liu, and C. Du, "Landsat-based long-term monitoring of total suspended matter concentration pattern change in the wet season for Dongting Lake, China," Remote Sens., vol. 7, no. 10, pp. 13975-13999, 2015.

[6] J. A. Sobrino, J. C. Jiménez-Muñoz, and L. Paolini, "Land surface temperature retrieval from LANDSAT TM 5,” Remote Sens. Environ., vol. 90, no. 4, pp. 434-440, 2004.

[7] D. Kyryliuk and S. Kratzer, "Total suspended matter derived from MERIS data as indicator for coastal processes in the Baltic Sea.”

[8] B. Trisakti and A. N. D. S. Budhiman, "Study of modis-aqua data for mapping total suspended matter (tsm) in coastal waters," Indones. Natl. Inst. Aeronaut. Sp., vol. 2, no. 70, 2005.

[9] Zhengming Wan, "MODIS Land-Surface Temperature Algorithm Theoretical Basis Document (LST ATBD)," 1999.

[10] H. Wibisana, S. Zainab, and N. Handajani, “Analisa Konsentrasi Klorofil-A pada Pesisir Pantai Berbasis Parameter Nilai Reflektans Citra Satelit Aqua Modis,” Semin. Nas. Geomatika, vol. 0, no. 0, pp. 301-307, 2016.

[11] P. J. Minnett and A. Science, "Satellite Oceanography: Sea-Surface Temperature and Climate Data Records.”

[12] Y. Wang, H. Jiang, J. Jin, X. Zhang, X. Lu, and Y. Wang, "Spatial-temporal variations of chlorophyll-a in the adjacent sea area of the yangtze river estuary influenced by yangtze river discharge," Int. J. Environ. Res. Public Health, vol. 12, no. 5, pp. 5420-5438, 2015.

[13] Q. Guo et al., "Study on Retrieval of Chlorophyll-a Concentration Based on Landsat OLI Imagery in the Haihe River, China,” Sustainability, vol. 8, no. 8, p. 758, Aug. 2016. 